\title{
Microbial activity within a subaqueous dune in a large lowland river (River Elbe, Germany)
}

\author{
Sabine Wilczek ${ }^{1}$, Helmut Fischer ${ }^{1,2}$, Matthias Brunke ${ }^{1,3}$, Martin T. Pusch $^{1, *}$ \\ ${ }^{1}$ Leibniz-Institute of Freshwater Ecology and Fisheries, Müggelseedamm 310, 12587 Berlin, Germany \\ ${ }^{2}$ Present address: Department of Limnology, University of Uppsala, Norbyvägen 20, 75236 Uppsala, Sweden \\ ${ }^{3}$ Present address: Landesamt für Natur und Umwelt Schleswig-Holstein, Hamburger Chaussee 25, 24220 Flintbek, Germany
}

\begin{abstract}
Microbial processes within subaqueous dunes of large rivers are important for organic matter retention and decomposition but have rarely been examined. We investigated 3 morphodynamically defined zones (stoss side, crestal plateau, and lee side) within a subaqueous dune in the 8th-order River Elbe. Analysis of flow velocity, vertical hydraulic gradient, concentration of mobile fine interstitial particles, and the quantity and biochemical quality of sedimentary organic matter indicated that the stoss and the lee sides of the dune were focal zones of particulate matter retention due to infiltration and sedimentation processes. Bacterial abundance and most measures of microbial activity (sediment community respiration and activities of the extracellular enzymes $\beta$-glucosidase, leucine aminopeptidase, $\beta$-xylosidase, and exo-1,4- $\beta$-glucanase) were significantly higher in these zones than in the plateau. Increases in bacterial abundance and microbial activity were closely correlated with protein, carbohydrates, nitrogen and phaeopigments associated with high-quality particulate organic matter. Our findings showed that the morphodynamic differentiation of the subaqueous dune resulted in the formation of distinct functional zones in the sediment. The underlying mechanisms can be conceptually summarized by a 2-stage regulatory hierarchy. Microbial activities were controlled directly by the input of dissolved oxygen and easily degradable microbial substrates, and indirectly by hydromorphological processes. We conclude that the subaqueous dune functioned as an efficient filter of particulate organic matter, and that the stoss and the lee sides of this river bedform were focal sites of microbial carbon mineralisation in the large river ecosystem.
\end{abstract}

KEY WORDS: Extracellular enzymes · Particulate organic matter $\cdot$ Subaqueous dune $\cdot$ Sediments · River $\cdot$ Bacteria $\cdot$ Hydrodynamics

Resale or republication not permitted without written consent of the publisher

\section{INTRODUCTION}

In running water ecosystems, heterotrophic bacteria exclusively mediate many of the degradation and transformation processes of organic matter associated with benthic and hyporheic sediments (Vervier et al. 1993, Findlay \& Sobczak 2000), using specific enzymatic systems (Chróst 1991). The microbial degradation of dissolved and particulate organic matter (DOM and POM) in the sediments frequently dominates fluvial ecosystem metabolism (Rutherford et al. 1991, Naegeli \& Uehlinger 1997, Fischer \& Pusch 2001). Since bacterial uptake mechanisms are restricted to small molecules, polymeric substrates have to be cleaved extracellularly (Chróst 1994). Therefore, it is assumed that the activity of extracellular hydrolytic enzymes potentially limits the rate of microbial breakdown of organic matter (Chróst 1991). Studies on extracellular enzyme activities (EEA) give insight into the relative decomposition rates of specific fractions of organic matter. Hence, this approach provides a functional profile of microbial activity that supplements the more general measures of microbial metabolism such as respiration rate and bacterial abundance (Sinsabaugh \& Linkins 1990). However, the EEA in the sediments of rivers have rarely been studied (Sinsabaugh 
\& Findlay 1995, Battin \& Sengschmitt 1999, Romaní \& Sabater 1999).

In river sediments, aerobic microbial activity depends on the supply rate of organic matter, nutrients, and oxygen from river flow that includes groundwater and the overlying surface water (Vervier et al. 1993, Brunke \& Gonser 1997, Valett et al. 1997). The organic matter supply from overlying surface water is largely controlled by the morphological structure of the riverbed (Hendricks 1993), because natural bedforms cause spatial and temporal variation in the local vertical hydraulic gradient (VHG) which indicate vertical water exchange (Williams 1993, Rutherford 1994). This exchange ('pumping') is a combination of infiltration of overlying surface water into the bed sediment, longitudinal hyporheic flow and exfiltration of hyporheic water (Elliot \& Brooks 1997). With infiltrating overlying surface water, dissolved and suspended organic matter is transferred into the sediment (advective transport). In contrast to simple deposition, advective transport provides a fast pathway for fresh degradable particles to reach deeper sediments (Huettel et al. 1996). An additional mechanism creating exchange of water and substrate between sediment and overlying surface water is formed by the shifting of bedforms that trap and release interstitial water and particles when moving (Elliot \& Brooks 1997, Packman \& Bencala 2000). Both exchange processes, infiltration of overlying surface water and shifting of bedforms, influence the activity of microorganisms of the sedimentary biofilm (Pusch et al. 1998, Fischer et al. 2003).

The spatial variation and microbial processing of organic matter in bedforms have usually been studied in stream riffles (e.g. Hendricks 1993, Pusch \& Schwoerbel 1994). There is little direct evidence of the biogeochemical functioning of sediment bedforms in larger rivers. Current knowledge comes from studies on individual gravel bars near the river margin and their inflow-outflow balance of matter (Vervier \& Naiman 1992, Claret et al. 1997). These studies have shown that gravel bars act as sinks for dissolved organic carbon (DOC), suggesting that such bedforms may act as filters for organic matter.

In large lowland rivers, the river bed consists mainly of sand, which is almost permanently transported as bed load (Sauer \& Schmidt 2001), and thereby may form huge subaqueous dunes. These dunes are hydromorphologically divided into 3 zones: upstream side (stoss side), crestal platform (plateau) and downstream side (lee side), which differ in hydrodynamics and sediment transport (Carling et al. 2000, Kostaschuk 2000). The stoss side of dunes is commonly characterized by increased near-bed velocity and a negative VHG, indicating infiltration of surface water and dissolved and particulate matter into the sediments (Carling et al.
2000). Near the crest, especially in cases where a crestal platform (plateau) exists, near-bed velocity decreases, paralleled by decreasing infiltration and sedimentation rates. On the lee side, reverse flow may occur and, due to the low near-bed velocity, only minor infiltration occurs (Carling et al. 2000, Kostaschuk 2000). Reduced flow velocities and shifting of the sediment structure may result in the burial of particulate matter on the lee side.

In this study, we aimed to gain a better insight into the function of the river sediment 'filter'. Our objective was to determine whether a sand bedform on the bottom of a large sandy river exhibits distinct biogeochemical organisation, as has been demonstrated for the gravel bars of smaller streams and rivers. More specifically, we hypothesized that EEA and sediment community respiration (SCR) rates would differ within several functional zones of the bedform, due to the varying input of DOM and POM. Thus, we quantified the spatial distribution of significant microbial activities within the sediments of a subaqueous dune and their control by abiotic variables.

\section{MATERIALS AND METHODS}

Study site. The study site was located in the River Elbe, an 8th-order river at a station $598 \mathrm{~km}$ from its source $\left(51^{\circ} 51^{\prime} \mathrm{N}, 12^{\circ} 28^{\prime} \mathrm{E}\right.$, Fig. 1A) near the town of Coswig. The river slope in this section is about $0.021 \%$. The water quality is mainly influenced by mass development of planktonic algae due to high nutrient loads. Data on discharge and physicochemical variables in the river water on 13 September and 14 November and annual means and ranges are given in Table 1 . The Elbe is a navigable river. Thus, the banks are protected by stone groynes built perpendicularly to the flow direction (Fig. 1B) at a distance of about $100 \mathrm{~m}$ from each other. The 3-dimensional subaqueous bedform, typically dune-shaped, was located near the tip of a groyne (Fig. 1C) at the margin of the navigation channel, when water level was low. On the sampling dates in September 2000, the total channel width was approximately $100 \mathrm{~m}$, and the subaqueous dune was located about $10 \mathrm{~m}$ from the river bank. The dune remained stationary between August 2000 and November 2000, because bed load transport was low during this period. The morphology of the subaqueous dune was mapped by a Sonar Lite portable echosounder system (OHMEX Instruments, L. M. Technical Services), with a vertical resolution of $0.01 \mathrm{~m}$, longitudinal resolution of $1 \mathrm{~m}$, and lateral resolution of $0.3 \mathrm{~m}$. The subaqueous dune was seasonally immobile, but disappeared later in winter, probably due to a considerable increase in river discharge. Echo-sounding 
measurements conducted on the midchannel river bottom in the River Elbe near the city of Coswig (river km 598.0 to 599.4) showed that the river bottom was partially covered by mobile long dunes, with a plateau length of $>100 \mathrm{~m}$ (Wang et al. 2002). These mobile bedforms were mostly flatter than the investigated subaqueous dune. Similar long flat dunes also cover the river bottom in the River Rhine (Carling et al. 2000).

Sampling procedure. The subaqueous dune near the tip of a groyne was sampled in 3 morphodynamical zones, upstream = stoss side, crestal platform = plateau, and downstream = lee side; 3 sampling positions were located within the stoss and lee sides respectively, and 6 positions within the plateau (3 on the upper plateau towards the stoss, and 3 on the lower plateau towards the lee side) (see Fig. 2). Samples were collected on 12 and 13 September 2000 and on 14 November 2000. At each position, piezometers (steel pipes, internal diameter $5 \mathrm{~cm}$ ) with perforations (diameter $5 \mathrm{~mm}$ ) were inserted into the sediment to a

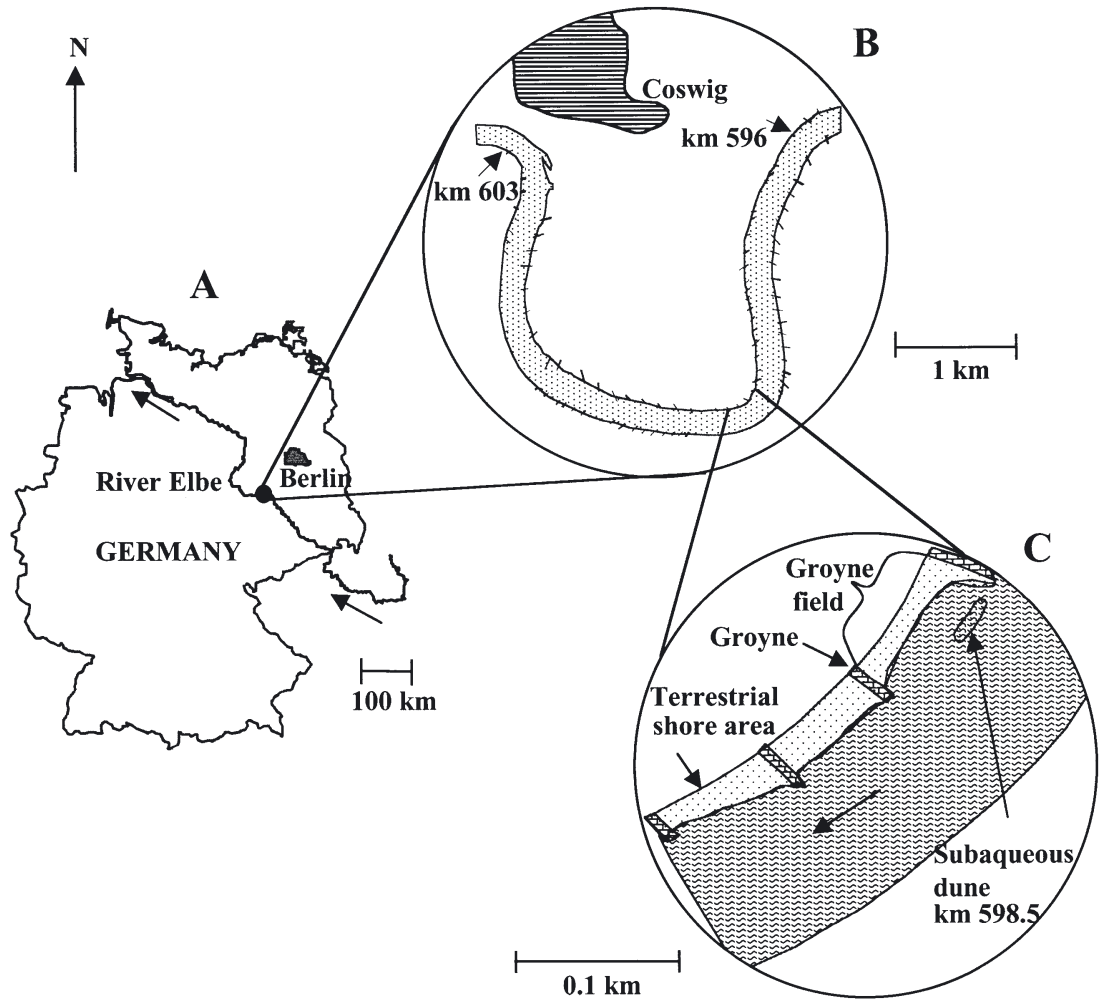

Fig. 1. Location of study site: (A) Map of Germany showing River Elbe. (B) Investigated river reach near Coswig town; $\mathrm{km}=$ river kilometres counted from source; whiskers along river margin = groynes. (C) Subaqueous dune and 3 groyne fields investigated at the sampling site depth of $0-5 \mathrm{~cm}$. In the following, this depth level is described as $5 \mathrm{~cm}$ depth.

For the collection of sediments, $10 \mathrm{l}$ of interstitial water were extracted with a hand pump after discarding the first 21 (Bou \& Rouch 1967, Brunke \& Fischer 1999). The fine particle fraction of sediment passing a $90 \mu \mathrm{m}$ mesh net was filtered onto Whatman GF/F filters. This particle fraction of $\sim 0.7$ to $90 \mu \mathrm{m}$ (d50 [median sedi-

Table 1. Discharge, and physicochemical variables of Elbe river water near the town of Coswig (Wittenberg) in 2000 (data provided by Wassergütestelle Elbe)

\begin{tabular}{|c|c|c|c|c|}
\hline \multirow[t]{2}{*}{ Parameter } & \multicolumn{2}{|c|}{ Annual } & \multirow[t]{2}{*}{13 Sep } & \multirow[t]{2}{*}{14 Nov } \\
\hline & mean & range & & \\
\hline Discharge $\left(\mathrm{m}^{3} \mathrm{~s}^{-1}\right)$ & 349 & $129-1900$ & 146 & 162 \\
\hline Temperature $\left({ }^{\circ} \mathrm{C}\right)$ & 9.2 & $2.9-24.3$ & 19.8 & 7.8 \\
\hline $\mathrm{pH}$ & 7.7 & $7.1-9.0$ & 7.9 & 7.5 \\
\hline Conductivity $\left(\mu \mathrm{S} \mathrm{cm}^{-1}\right)$ & 434 & $330-580$ & 500 & 505 \\
\hline Dissolved oxygen $\left(\mathrm{mg} \mathrm{l}^{-1}\right)$ & 11.4 & $8.8-13.2$ & 9.1 & 10.4 \\
\hline Ammonium $\left(\mathrm{mg} \mathrm{l}^{-1}\right)$ & 0.33 & $<0.01-0.82$ & $<0.02$ & 0.13 \\
\hline Nitrite $\left(\mathrm{mg} \mathrm{l}^{-1}\right)$ & 0.04 & $<0.01-0.07$ & 0.02 & 0.05 \\
\hline Nitrate $\left(\mathrm{mg} \mathrm{l}^{-1}\right)$ & 4.5 & $3.1-5.7$ & 4.0 & 4.3 \\
\hline Total phosphorus (mg l $\left.\mathrm{l}^{-1}\right)$ & 0.22 & $0.16-0.4$ & 0.23 & 0.21 \\
\hline Total organic carbon $\left(\mathrm{mg} \mathrm{l}^{-1}\right)$ & 7.8 & $5.2-11$ & 8.5 & 5.7 \\
\hline Dissolved organic carbon $\left(\mathrm{mg} \mathrm{l}^{-1}\right)$ & 4.4 & $3.9-5.3$ & 5.3 & 4.7 \\
\hline Chlorophyll a $\left(\mu \mathrm{g} \mathrm{l}^{-1}\right)$ & 39.2 & $1.2-195$ & 120 & 11 \\
\hline
\end{tabular}

ment diameter] ranges between 3 and $8 \mu \mathrm{m}$ in the Elbe) is moved by interstitial flow within the framework sediment (Brunke \& Gonser 1999, M. Brunke unpubl. data) and is therefore referred to in the following as mobile fine interstitial particles (MFIP). Dry mass, particulate organic carbon (POC) and particulate nitrogen (PN) content were determined separately in the MFIP in order to examine its role as substrate and colonisation site. The coarse particle fraction of sediment $>90 \mu \mathrm{m}$ to $5 \mathrm{~mm}$, which contributed about $70 \%$ to the total sediment particles, is referred to in the following as sediment. Subsamples of sediment were taken in order to determine the contents of total POM, POC, PN, particulate carbohydrates and particulate protein, as well as bacterial abundance and the activity of 4 extracellular enzymes. Interstitial water was collected by inserting a submersible electric pump with $90 \mu \mathrm{m}$ mesh net immediately after the sediment samples had been taken. In these 
samples, chlorophyll a (chl a) and phaeopigments, DOC and physicochemical variables (temperature, conductivity, $\mathrm{pH}$, dissolved oxygen concentration) were analysed. Additionally, 2 samples of surface water were collected on 13 September and 14 November in order to determine chl $a$, phaeopigments, bacterial abundance, activities of 4 extracellular enzymes and physicochemical variables (temperature, conductivity, $\mathrm{pH}$, dissolved oxygen). The samples for $\mathrm{chl} a$ and phaeopigments in interstitial water and surface water were filtered onto Whatman GF/F filters. Samples of MFIP, sediment and surface water were immediately stored on ice until being processed in the laboratory within $20 \mathrm{~h}$.

Flow velocity and vertical hydraulic gradient (VHG). Flow velocity was measured with a 'FlowMate' (Model 2000, Marsh-McBirney) $5 \mathrm{~cm}$ above the sediment surface at each sampling position. VHG was calculated as the difference in hydraulic head divided by depth of the piezometer $(25 \mathrm{~cm})$. Negative VHG values relate to lower water pressure within the interstices compared to the stream, indicating infiltration. Positive VHG values relate to higher water pressure within the interstices compared to the stream, indicating exfiltration.

Chemical analyses. Prior to DOC analysis, interstitial water samples were filtered through pre-rinsed cellulose acetate filters (pore size $0.45 \mu \mathrm{m}$ ). DOC was quantified by liquid chromatography followed by organic carbon detection (LC-OCD). This technique fractionates DOC via size-exclusion chromatography and allows separation and quantification of various groups of DOC, namely polysaccharides, humic substances, low-molecular-weight carboxylic acids and low-molecular-weight amphiphilic substances (Fischer et al. 2002a).

Sediment particle size distribution. In order to determine particle size distribution and the sorting coefficient $(\mathrm{d} 10 / \mathrm{d} 60)^{0.5}(10 \%=\mathrm{d} 10$ and $60 \%=\mathrm{d} 60$ of total sediment passing through sieve), complete sediment samples from each sampling position were taken with a sediment corer, dried at $105^{\circ} \mathrm{C}$, and sieved through a standard set of sieves with mesh sizes decreasing from $20 \mathrm{~mm}$ to $63 \mu \mathrm{m}$.

Particulate matter in MFIP and sediment. GF/F filters with MFIP, and sediment samples $(\sim 0.7-90 \mu \mathrm{m})$ were dried to constant weight at $105^{\circ} \mathrm{C}$. Total POM was determined as loss on ignition in sediment samples. For this purpose, 15-25 g wet weight of sediment samples were subsequently combusted for $6 \mathrm{~h}$ at $550^{\circ} \mathrm{C}$ in order to determine POM as ash-free dry mass. The POC and PN contents of dried MFIP filters and dried sediment samples were determined using a CNS (carbon, nitrogen, sulfur) analyser (Vario EL, Elementar Analysensysteme). Dried sediment samples were ground prior to analysis with an analytical ball mill (Pulverisette 6, Fritsch) for $15 \mathrm{~min}$, and inorganic carbon was removed from both MFIP and sediment samples with $1 \mathrm{M} \mathrm{HCl}$. Triplicate subsamples of sediments were filled into cylindrical silver foil capsules (9 mm height, $5 \mathrm{~mm}$ diameter; Lüdi AG), while duplicate subsamples of MFIP filters were wrapped in aluminum foil for analysis. The calibration curve was established using acetanilide (limit of detection $\mathrm{C}<$ $0.004 \mathrm{mg} ; \mathrm{N}<0.004 \mathrm{mg}$ ). $\mathrm{C} / \mathrm{N}$ ratios were calculated as molar ratios. Protein was extracted from sediment samples according to Rausch (1981) quantified using the micro-biuret method of Itzhaki \& Gill (1964). Total carbohydrates of sediment samples were extracted by a phenol-sulfuric acid assay according to Underwood \& Parkers (1995). The absorbance of the extracted carbohydrates was then measured against a reagent blank at $485 \mathrm{~nm}$ using a glucose standard. Hot ethanol $\left(90 \%, 78^{\circ} \mathrm{C}\right)$ was used for the extraction of $\mathrm{chl}$ $a$ and phaeopigments in MFIP and surface water. Extraction occurred for $12 \mathrm{~h}$ at room temperature in the dark. The clear ethanol-pigment-mixture was used to determine chl $a$ and phaeopigments with a spectrophotometer (UV-2401 PC, Shimadzu) according to DIN 38412-L16 (German standard methods: Deutsche Einheitsverfahren 1985).

Bacterial abundance. Bacterial abundance was determined in surface water and sediments. The subsamples for bacterial abundance were fixed in a sterile-filtered aqueous solution containing 3.5\% formaldehyde, $0.85 \% \mathrm{NaCl}$, and $1 \mathrm{mM}$ pyrophosphate (final concentration). After a $10 \mathrm{~min}$ sonication step and rigorous vortexing of all samples, supernatants of sediment subsamples were diluted again (dilution factor $=25$ ). Samples for bacterial cell counts in sediments were taken from the supernatant, and samples of surface water were used directly. Bacteria were stained using 4', 6-diamidino-2-phenylindiol (DAPI) (Porter \& Feig 1980) at a final concentration of $10 \mathrm{mg} \mathrm{l}^{-1}$. After 40 min of dark incubation, bacteria were filtered onto black polycarbonate filters (Nuclepore, pore size $0.2 \mu \mathrm{m}$ ) and mounted on slides using anti-fading solution (AF1, Citifluor, London). At least 200 bacteria within a total of at least 10 microscopic fields were counted by epifluorescence microscopy (Nikon FXA Microscope, HBO 100 W, Ex 330-380, DM 400, BA 400, immersion objective CF N DIC Plan Achromate 100×).

Extracellular enzyme activities (EEA). We use the term 'extracellular enzymes' for all enzymes that act extracellularly, including those attached to bacterial cells and particles and also free enzymes in the liquid phase. EEA were determined in surface water and sediments. Fluorogenic substrate analogues (methylcumarinyl [MCA]-substrates and methylumbelliferyl [MUF]-substrates, Sigma) were used to measure the 
potential EEA ( $\left.V_{\max }\right)$ of $\beta$-D-xylosidase (degrades xylobiose), $\beta$-D-glucosidase (degrades cellobiose), exo-1,4$\beta$-glucanase (degrades cellulose), and leucine aminopeptidase (LAP) (degrades peptides) (Hoppe 1993, Marxsen et al. 1998). We prepared 3 replicates and 2 controls of each sediment sample using $3 \mathrm{~g}$ of wet sediment (volume was determined) and $8 \mathrm{ml}$ of filtered $(0.2 \mu \mathrm{m})$ interstitial water. For measuring EEA in surface water, 3 replicates and 2 controls were prepared using $8 \mathrm{ml}$ of surface water directly. After boiling the controls for $30 \mathrm{~min}, 1 \mathrm{ml}$ of the substrate analogue was added to replicates and controls. The substrate analogue were added in saturation concentrations, which were determined in previous experiments using sediments and surface water from the study site (sediment samples LAP: $400 \mu \mathrm{M}, \beta$-glucosidase: $350 \mu \mathrm{M}$, exo-1,4$\beta$-glucanase and $\beta$-xylosidase: $300 \mu \mathrm{M}$; surface water samples: LAP: $150 \mu \mathrm{M}, \beta$-glucosidase, exo-1,4- $\beta$-glucanase and $\beta$-xylosidase: $120 \mu \mathrm{M}$ ). All samples (replicates and controls) were incubated for $1-3 \mathrm{~h}$ at ambient river temperature $\left(20^{\circ} \mathrm{C}\right.$ in September and $8^{\circ} \mathrm{C}$ in November) in the dark under continuous shaking (rotational frequency $70 \mathrm{~min}^{-1}$ ), and killed by boiling for $3 \mathrm{~min}$. When cooled to room temperature, $1 \mathrm{ml}$ of $0.1 \mathrm{M}$ alkaline glycine buffer $(\mathrm{pH} 10.5)$ was added. After centrifugation $(5 \mathrm{~min}$ at $4000 \times g)$, hydrolysis of the substrate analogue was measured by determining the fluorescence of the supernatant (Shimadzu RF$5001 \mathrm{PC}$ spectrofluorometer, $1.5 \mathrm{~nm}$ slit, $360 \mathrm{~nm}$ (MCA) or $365 \mathrm{~nm}$ (MUF) excitation, $440 \mathrm{~nm}$ (MCA) or $450 \mathrm{~nm}$ (MUF) emission). Standard MCA (7-amino-4-methylcoumarin) solutions and standard MUF (4-methylumbelliferone) solutions were used for calibration.

Sediment community respiration (SCR). SCR was measured using sediment chambers perfused with river water (after Pusch \& Schwoerbel 1994, modified). Sediments were retrieved by hand horizontally from the upper sediment layer $(0-6 \mathrm{~cm})$ and scooped below the water surface into a respiration chamber made of clear plastic pipe $(18 \mathrm{~cm}$ long, $6 \mathrm{~cm}$ inside diameter, volume, $V=0.51 \mathrm{l}$ ). The chambers were sealed under water with caps covered by nylon mesh $(0.2 \mathrm{~mm}$ meshsize) and subsequently stored in ice water for up to $3 \mathrm{~d}$. In the laboratory, chambers were connected to a stirred, high-resolution oxygen probe (Type 4002, Syland Scientific), and an adjustable, electromagnetically clutched precision pump (Type GAMMA/ 4 -W, Prominent Dosiertechnik) and installed in a oncethrough, upward-flow system. The incubation system was perfused with river water at $20 \pm 1^{\circ} \mathrm{C}$ in September and $8 \pm 1^{\circ} \mathrm{C}$ in November. Temperature and oxygen concentrations were continuously recorded. Perfusion was terminated when oxygen concentration in the outflow of the chamber remained stable for at least 30 min. Perfusion time and flow-through rate $\left(q, 1 \mathrm{~h}^{-1}\right)$ were recorded. The oxygen content of river water bypassing the sediment chamber was measured as control. SCR ( $\mathrm{mg} \mathrm{l}^{-1}$ sediment) was calculated using the difference in oxygen concentration between the control and the perfused water $\left(\Delta \mathrm{O}_{2}, \mathrm{mg} \mathrm{l}^{-1}\right)$ related to the volume of sediment chamber $(V)$

$$
\mathrm{SCR}=\frac{\Delta \mathrm{O}_{2} q}{V}
$$

Statistical analyses. Data from the September and November sampling dates were pooled for analyses. As the data did not show normal distributions (Shapiro-Wilk test), non-parametrical Kruskal-Wallis $H$-tests were used to examine the variability of microbial activity, POM content, sedimentological and hydrological variables between the morphodynamical zones (stoss side, plateau, lee side) of the dune. After detecting a significant difference $(p<0.05)$, we compared the zones of the dune by pairs using the MannWhitney $U$-test. Data were transformed by the natural logarithm to reduce skewness and kurtosis prior to principal components analyses (PCA). The PCA was conducted on the microbial and environmental variables to detect the factors which explained their variability and to detect differences along the transect of the dune (Thioulouse et al. 1997). Bacterial abundance and VHG were correlated (Spearman rank correlations) with PCA fractional scores 1 and 2 to test for relationships with variables included in the PCA. Spearman rank correlations were also used to reveal relationships between microbial and environmental variables.

\section{RESULTS}

\section{Dune morphology, granulometry and hydrodynamics}

The subaqueous dune was nearly $40 \mathrm{~m}$ in length and $12 \mathrm{~m}$ in width, clearly discernible, with a long stoss side, a crestal platform (plateau) and a lee side (Fig. 2).

Sediment particle sizes on the stoss and the lee sides differed significantly from those on the plateau. The median (d50) was highest at the plateau $(2.7 \mathrm{~mm})$ followed by the stoss $(1.9 \mathrm{~mm})$, and the lee side $(1.3 \mathrm{~mm})$. Fine gravel $(2.0-6.0 \mathrm{~mm})$ dominated on all zones (stoss side: $52 \%$; plateau: $49 \%$; lee side: $43 \%$ ), followed by coarse sand $(0.6-2.0 \mathrm{~mm})$ on the stoss and the lee sides (stoss side: $26 \%$; lee side: $38 \%$ ), and by medium gravel $(6.0-20.0 \mathrm{~mm})$ on the plateau $(31 \%)$. A small fraction $(0.17 \%)$ of coarse gravel $(20.0-60.0 \mathrm{~mm})$ was also encountered on the plateau. Fine sand fractions were low at all sites. The stoss (median 0.50) and the lee (median 0.51 ) sides had significantly higher sorting coefficients $\left((\mathrm{d} 60 / \mathrm{d} 10)^{-0.5}\right)$ than the plateau (median 0.35$)$. 


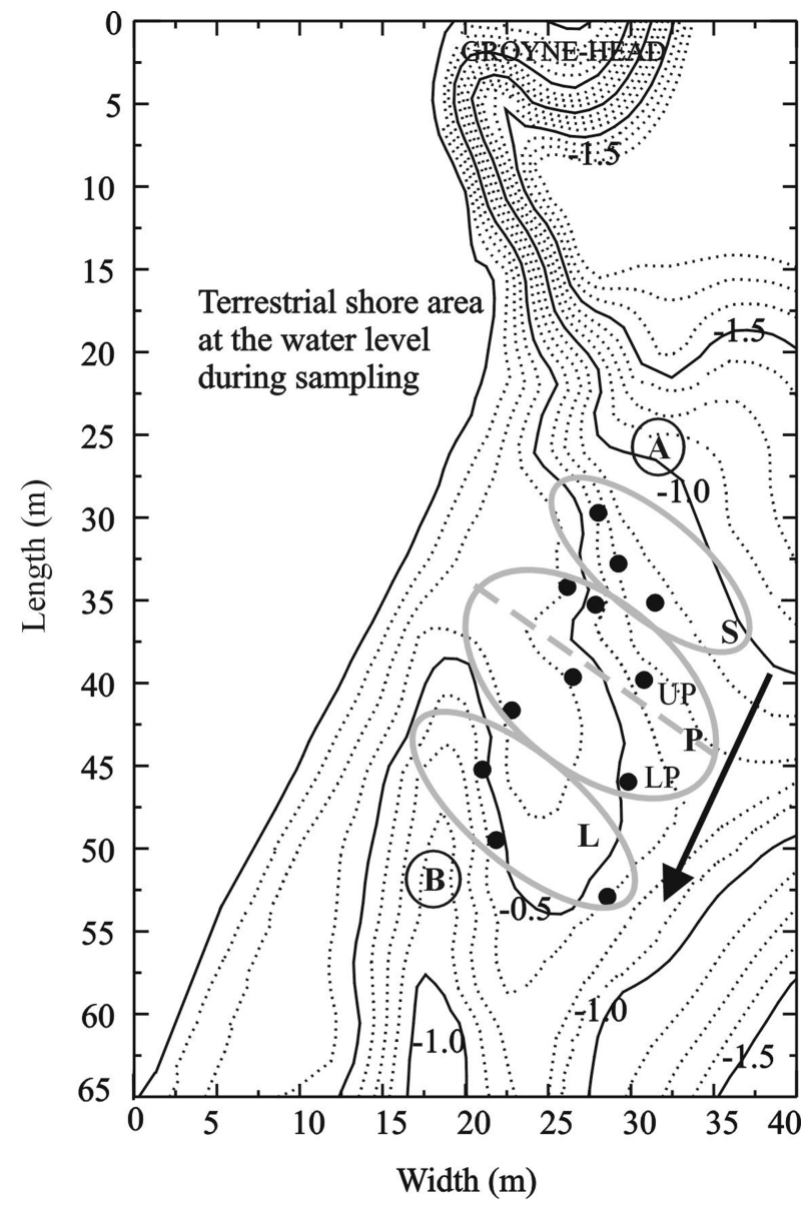

Fig. 2. Contour map showing water depths at study site and sampling positions (-) along transect (A-B) within the 3 morphodynamic zones (stoss, plateau, lee) of subaqueous dune. S: stoss side; P: plateau; UP: upper plateau; LP: lower plateau; L: lee side; arrow indicates flow direction

Flow velocities $5 \mathrm{~cm}$ above the sediment surface were significantly higher on the plateau (median $40.2 \mathrm{~cm} \mathrm{~s}^{-1}$ ) than the stoss (median $34.3 \mathrm{~cm} \mathrm{~s}^{-1}$ ) and the lee (median $3.3 \mathrm{~cm} \mathrm{~s}^{-1}$ ) sides. The flow velocities on the stoss side were significantly higher than those on the lee side. VHG values on the stoss side were usually negative, and increased towards the upper and lower plateau, and then gradually decreased on the lee side (Fig. 3A, Table 2); thus, infiltration prevailed on the stoss side, and exfiltration prevailed in the other zones. Significant differences in VHG were found between the stoss side and plateau.

\section{Mobile fine interstitial particles (MFIP < $90 \mu \mathrm{m})$}

The dry mass of MFIP and content of PN and POC were significantly different between the zones of the dune (Kruskal-Wallis $H$-test; Table 2). The stoss side exhibited significantly higher dry mass and contents of PN and POC in the MFIP (Fig. 3B,C) than the other 2 zones of the dune. The $\mathrm{C} / \mathrm{N}$ ratios of MFIP showed no significant differences between the zones, but the $\mathrm{C} / \mathrm{N}$ ratios in September were significantly lower than the $\mathrm{C} / \mathrm{N}$ ratios in November (Fig. 3D). Notably, the $\mathrm{C} / \mathrm{N}$ ratios of MFIP (median 8.2) were significantly lower (Wilcoxon test, $\mathrm{p}=0.0001$ ) than the $\mathrm{C} / \mathrm{N}$ ratios of sedimentary POM (median 14.7) (Fig. 4F). Chl a content was not significantly different between the different zones (Fig. 3E); however, the phaeopigments within the MFIP did differ significantly between the 3 zones of the sand dune. The content of phaeopigments was significantly higher on the stoss side, compared to the plateau (Fig. 3F). Dry mass, $\mathrm{PN}, \mathrm{POC}$ content and phaeopigments of MFIP were strongly negatively correlated with VHGs $\left(\mathrm{r}_{\mathrm{s}}=-0.71\right.$, $-0.70,-0.75,-0.70$ respectively; $\mathrm{p}<0.01$ ); thus, these variables were highest where infiltration of river water occurred.

Table 2. Results of Kruskal-Wallis $H$-test testing differences of microbial and environmental variables between the 3 morphodynamical zones (stoss side, plateau, lee side) of subaqueous dune $(\mathrm{df}=2)$; levels of significance $=p<0.05, p<0.01$, $\mathrm{p}<0.001$. ns: not significant $(\mathrm{p}>0.05)$. MFIP: mobile fine interstitial particles

\begin{tabular}{|c|c|c|}
\hline $\begin{array}{l}\text { Microbial and } \\
\text { environmental variables }\end{array}$ & Chi-square & $\mathrm{p}$-value \\
\hline \multicolumn{3}{|l|}{ Granulometry and hydrodynamics } \\
\hline Sorting coefficient sediment & 7.3 & $<0.05$ \\
\hline d50 (median sediment diameter) & 8.6 & $<0.05$ \\
\hline Flow velocity & 24.6 & $<0.001$ \\
\hline Vertical hydraulic gradient & 6.3 & $<0.05$ \\
\hline \multicolumn{3}{|l|}{ MFIP variables } \\
\hline Dry mass MFIP & 12.7 & $<0.01$ \\
\hline POC MFIP & 12.3 & $<0.01$ \\
\hline PN MFIP & 12.9 & $<0.01$ \\
\hline $\mathrm{C} / \mathrm{N}$ ratio $\mathrm{MFIP}$ & 2.2 & ns \\
\hline Chlorophyll a MFIP & 2.7 & ns \\
\hline Phaeopigment MFIP & 6.8 & $<0.05$ \\
\hline \multicolumn{3}{|l|}{ Particulate matter of sediment } \\
\hline Total POM & 4.2 & ns \\
\hline POC & 2.8 & ns \\
\hline $\mathrm{PN}$ & 6.3 & $<0.05$ \\
\hline $\mathrm{C} / \mathrm{N}$ ratio & 5.9 & $=0.05$ \\
\hline Carbohydrates & 7.0 & $<0.05$ \\
\hline Protein & 9.0 & $<0.05$ \\
\hline \multicolumn{3}{|l|}{ Microbial variables } \\
\hline Bacterial abundance & 8.3 & $<0.05$ \\
\hline Sediment community respiration & 7.4 & $<0.05$ \\
\hline$\beta$-glucosidase activity & 10.5 & $<0.01$ \\
\hline Exo-1,4- $\beta$-glucanase activity & 13.5 & $<0.01$ \\
\hline$\beta$-xylosidase activity & 7.0 & $<0.05$ \\
\hline Leucine aminopeptidase activity & 8.2 & $<0.05$ \\
\hline
\end{tabular}


$\Delta \quad 12$ and 13 September 2000

ㅁ 14 November 2000

Fig. 3. (A) Vertical hydraulic gradient (VHG) along Transect A-B in September and November 2000. (B-F) Characteristics of mobile fine interstitial particles (MFIP) along transect of the 3 morphodynamic zones of the subaqueous dune. Plateau data are separated into 'upper plateau' (area near stoss side) and 'lower plateau' (area near lee side); (B) dry mass, (C) particulate nitrogen, (D) $\mathrm{C} / \mathrm{N}$ ratio (E) chlorophyll $a$ and (F) phaeopigment contents of MFIP. For each zone, medians are connected by dashed line
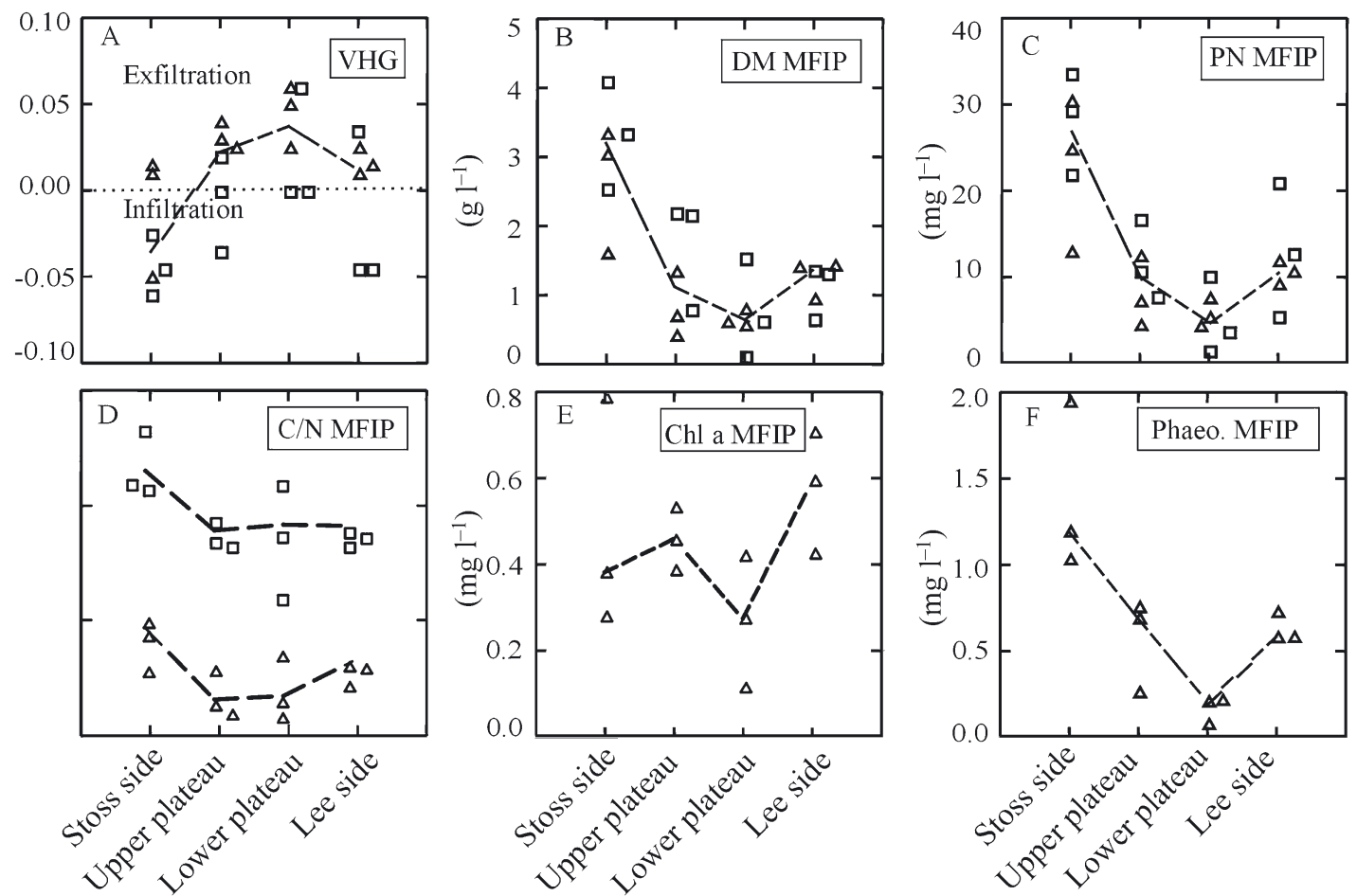

$\Delta \quad 12$ and 13 September 2000

ㅁ 14 November 2000

Fig. 4. Characteristics of sediment particulate matter along transect of the 3 morphodynamic zones of subaqueous dune in September and November 2000. Data shown separately for upper and lower plateau: (A) protein, (B) carbohydrates, (C) particulate nitrogen, (D) particulate organic carbon, (E) total particulate organic matter, $(\mathrm{F})$ $\mathrm{C} / \mathrm{N}$ ratio. For each zone, medians are connected by dashed line
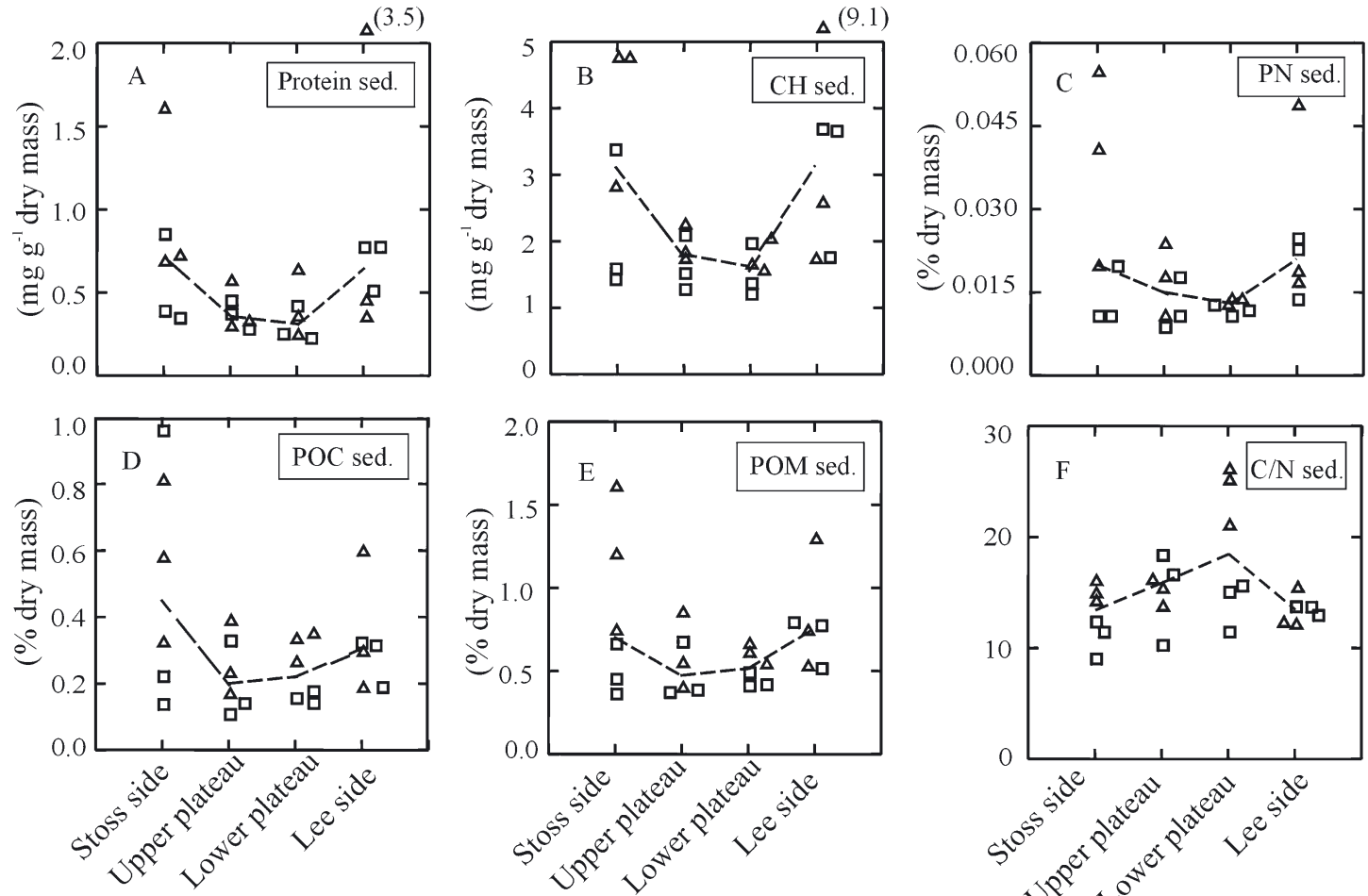

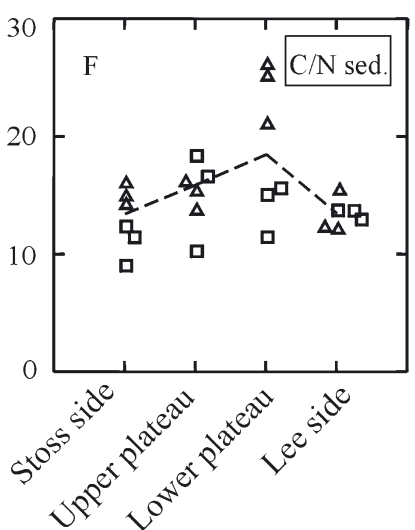

\section{Particulate matter of sediment $(>90-5 \mathrm{~mm})$}

The sediments of the subaqueous dune exhibited a median protein content of $0.44 \mathrm{mg} \mathrm{g}^{-1}$ dry mass and a median carbohydrate content of $1.92 \mathrm{mg} \mathrm{g}^{-1}$ dry mass. Protein and carbohydrate contents were significantly higher on the stoss and lee sides compared to the plateau (Fig. 4A,B). Additionally, the PN content (median $=0.0155 \%$ dry mass) was significantly higher on the lee side than the plateau (Fig. 4C), 
$\Delta$ 12 and 13 September 2000 14 November 2000

Fig. 5. Characteristics of bacterial variables along transect of the 3 morphodynamic zones of the subaqueous dune in September and November 2000. Data of plateau are shown separately for upper and lower plateau. (A) Bacterial abundance, (B) sediment community respiration, (C) leucine aminopeptidase, (D) $\beta$ glucosidase, (E) $\beta$-xylosidase, and (F) exo-1,4- $\beta$ glucanase. For each zone, medians are connected by dashed line. MCA: methylcumarinyl; MUF: methylumbelliferyl
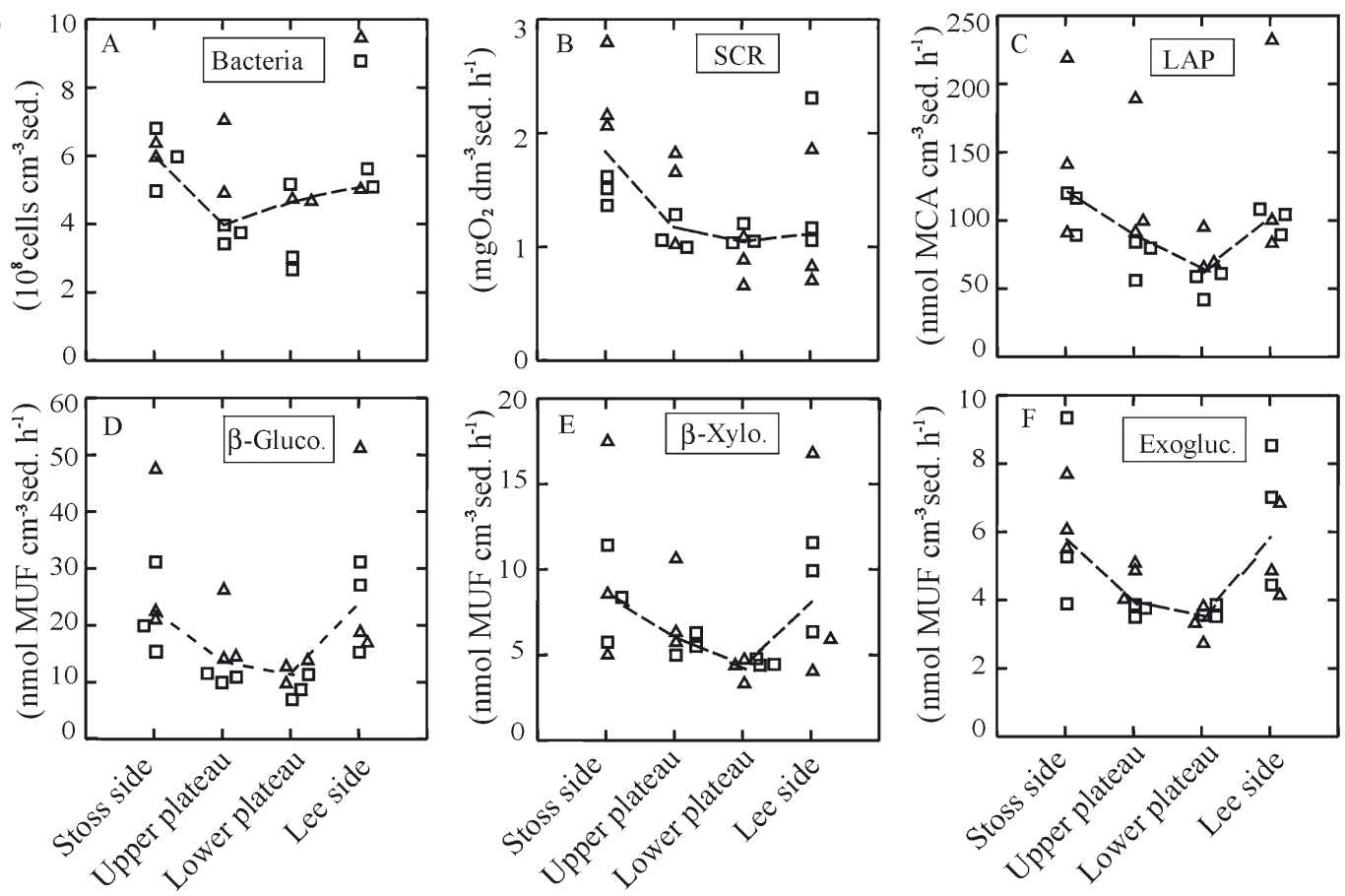

while POC (median $=0.28 \%$ dry mass) and total POM (median $=0.59 \%$ dry mass) contents were not significantly different between zones (Fig. 4D,E). Spatial variability of POM variables within a zone was especially high on the stoss and lee sides. The $\mathrm{C} / \mathrm{N}$ ratios did not vary significantly between zones, but tended to be lower on the stoss and lee sides in comparison with the plateau (Fig. 4F). Thus, the spatial pattern of sediment organic matter variables, protein, carbohydrates and $\mathrm{PN}$, showed a remarkable difference to that of the MFIP variables, which peaked only on the stoss side.

\section{Interstitial dissolved oxygen and various fractions of interstitial DOC}

Dissolved oxygen saturations were significantly higher on the stoss side (46\%) than the plateau (27\%). On the lee side, dissolved oxygen saturation reached $33 \%$. DOC did not differ significantly between the 3 morphodynamical zones of the dune (median = $4.4 \mathrm{mg} \mathrm{l}^{-1}$ ). Humic substances were the major DOC fraction, accounting for about $63 \%$ of the total DOC (median $=2.8 \mathrm{mg} \mathrm{l}^{-1}$ ), and showed only small variability along the transect. Free polysaccharide concentration decreased along the transect of the dune (stoss = $0.12 \mathrm{mg} \mathrm{l}^{-1}$, plateau $=0.098 \mathrm{mg} \mathrm{l}^{-1}$, lee $=0.081 \mathrm{mg} \mathrm{l}^{-1}$ ), although this pattern was not statistically significant. Low-molecular-weight acids and other low-molecular- weight substances comprised less than $1 \%$ of total DOC and did not show any consistent spatial pattern.

\section{Microbial variables}

Bacterial abundance in the dune sediments amounted to a median of $5.1 \times 10^{8}$ cells $\mathrm{cm}^{-3}$ sediment

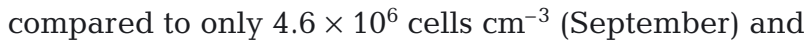
$4.0 \times 10^{6}$ cells $\mathrm{cm}^{-3}$ (November) in the water column. Bacterial abundance in the sediment was significantly higher on the stoss and lee sides than on the plateau (Fig. 5A). SCR reached a median of $1.2 \mathrm{mg} \mathrm{O}_{2} \mathrm{dm}^{-3}$ sediment $\mathrm{h}^{-1}$ and was significantly higher on the stoss side $\left(\right.$ median $=1.9 \mathrm{mg} \mathrm{O}_{2} \mathrm{dm}^{-3}$ sediment $\left.\mathrm{h}^{-1}\right)$ compared to the plateau and lee side (Fig. 5B).

Leucine aminopeptidase showed the highest activity $\left(\right.$ median $=92.7 \mathrm{nmol} \mathrm{MCA} \mathrm{cm}{ }^{-3}$ sediment $\mathrm{h}^{-1}$ ) (Fig. 5C) of the enzymes studied. Lower activities were found for $\beta$-glucosidase $\left(\right.$ median $=15.0 \mathrm{nmol} \mathrm{MUF} \mathrm{cm}^{-3}$ sediment $\mathrm{h}^{-1}$ ), $\beta$-xylosidase $\left(\right.$ median $=6.0 \mathrm{nmol} \mathrm{MUF} \mathrm{cm}^{-3}$ sediment $\mathrm{h}^{-1}$ ), and exo-1,4- $\beta$-glucanase (median = $4.4 \mathrm{nmol} \mathrm{MUF} \mathrm{cm}^{-3}$ sediment $\mathrm{h}^{-1}$ ) (Fig. 5D-F). EEA in sediments were about 50 to 300 times higher than in the water column. Activities of the 4 measured enzymes were significantly higher in the sediments of the stoss and lee sides compared to the plateau, with the exception of $\beta$-xylosidase activity, which showed only significant differences between the stoss side and plateau. Concomitant with high spatial variability of 
the POM content on the stoss and lee sides was a high spatial variability in EEA (Fig. 5C-F).

\section{Principal components analysis (PCA)}

The first 2 factors of the PCA of microbial and environmental parameters accounted for $73.6 \%$ of total variability. The first factor, which explained $54.1 \%$ of total variability, grouped bacterial activity (EEA, SCR) as well as sedimentary particulate matter variables (loss on ignition, POC, PN, carbohydrates and protein) (Fig. 6A). Samples with higher values of bacterial activity and sedimentary POM content are located on the left side of the ordination plot in Fig. 6A and samples with lower values on the right. Bacterial abundance was strongly negatively correlated with the first factor $\left(\mathrm{r}_{\mathrm{s}}=-0.82 ; \mathrm{p}<0.001\right)$. Correlation between VHG and the first factor was not as close as that for bacterial abundance $\left(r_{\mathrm{s}}=\right.$ $0.53 ; \mathrm{p}<0.01)$. Most samples from the stoss and the lee sides are located on the left side of the factorial map in Fig. 6B. In contrast, most samples from the plateau are located on the right side, indicating lower POM content, POM quality and microbial activity (Fig. 6B), with the lower plateau site exhibiting the lowest values on both sampling months. The ordination pattern thus reflects a clear spatial organisation within the dune.

The second factor, which explained 19.5\% of the total variability, was dominated by the $\mathrm{C} / \mathrm{N}$ ratio of $\mathrm{MFIP}$, and the $\mathrm{C} / \mathrm{N}$ ratio of sedimentary POM also affected this factor (Fig. 6A). VHG was significantly correlated with the second factor $\left(r_{\mathrm{s}}=0.62 ; \mathrm{p}<0.01\right)$. Samples with higher $\mathrm{C} / \mathrm{N}$ ratios in the sediment are located in the upper part of the factorial map, while samples with higher $\mathrm{C} / \mathrm{N}$ ratios of MFIP are located in the lower part of Fig. 6B. Thus, $\mathrm{C} / \mathrm{N}$ ratios of sediment POM contrast with $\mathrm{C} / \mathrm{N}$ ratios of MFIP. The $\mathrm{C} / \mathrm{N}$ ratios differed more between the 2 sampling months than between the various zones of the dune; all September samples are located in the upper part (higher $\mathrm{C} / \mathrm{N}$ ratio of sediment and lower $\mathrm{C} / \mathrm{N}$ ratio of $\mathrm{MFIP}$ ), and all November samples in the lower part (lower $\mathrm{C} / \mathrm{N}$ ratio of sediment and higher $\mathrm{C} / \mathrm{N}$ ratio of MFIP) of the ordination plot in Fig. $6 \mathrm{~B}$.

Hence, the ordination of the variables along the first-factor axis indicates a functional rela-

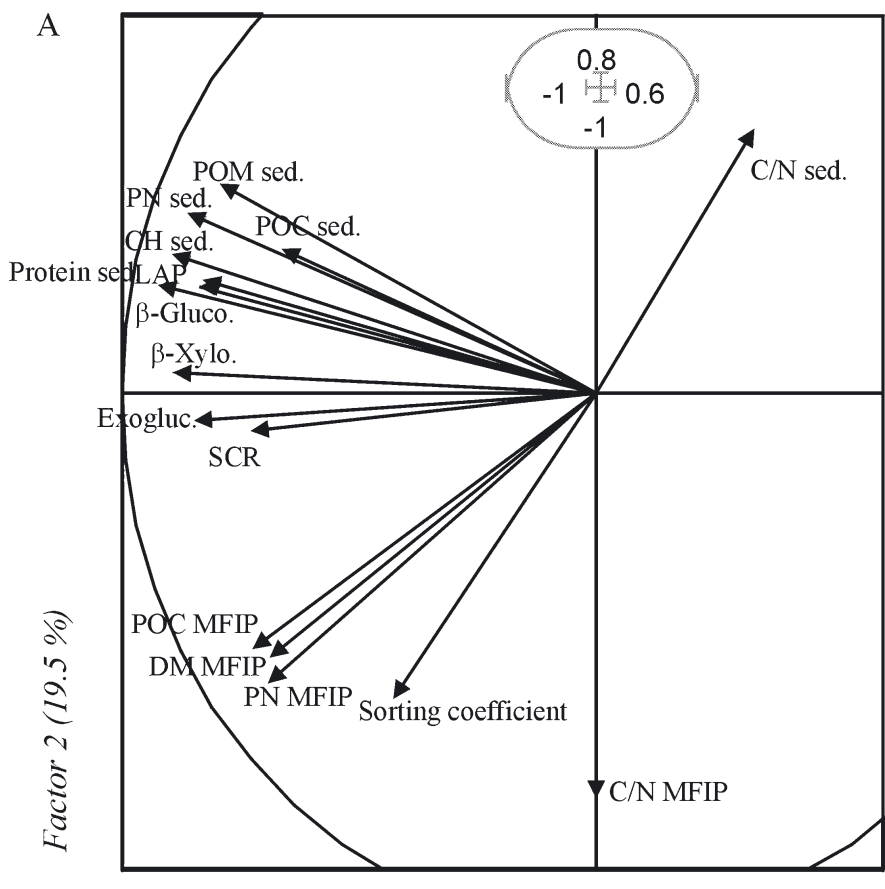

Factor $1(54.1 \%)$

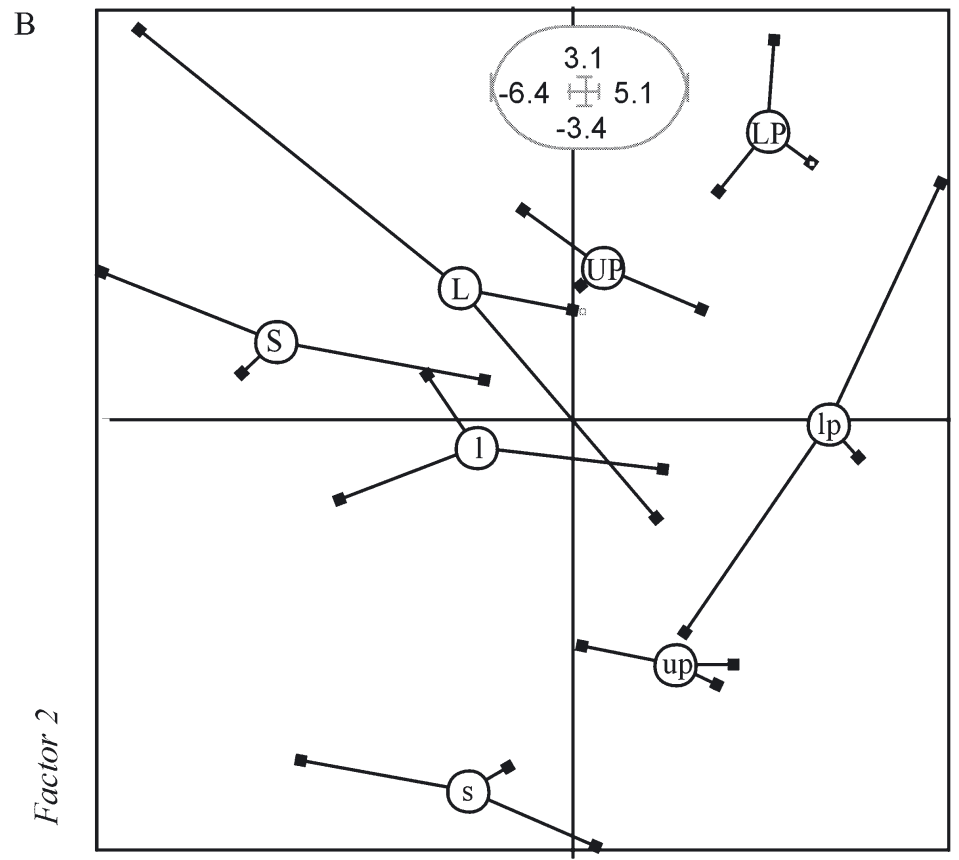

Factor 1

Fig. 6. (A) PCA ordination plot of bacterial and environmental variables. (B) Factorial map of different zones of subaqueous dune for the 2 sampling months. S: stoss side (September), UP: upper plateau (September); LP: lower plateau (September); L: lee side (September); s: stoss side (November); up: upper plateau (November); lp: lower plateau (November); 1: lee side (November). Other abbreviations as in

Figs. 3-5 
tionship between the parameters for sedimentary POM quantity and quality and microbial variables. The ordination of the variables along the second-factor axis indicates a control of POM quantity and quality by hydraulic transport, especially with regard to the mobile fraction of POM (MFIP).

\section{Relationships between microbial and environmental variables}

Microbial variables were closely correlated to environmental variables (Table 3) and negatively correlated to VHG for both sampling months. Also, bacterial abundance and EEA were strongly positively correlated with variables that indicate quality and quantity of sedimentary POM (protein, carbohydrates, PN, phaeopigments). Similarly, bacterial abundance and EEA were closely negatively correlated to the $\mathrm{C} / \mathrm{N}$ ratios in the September samples. The SCR correlated significantly with sedimentary protein, and highly significantly with the phaeopigment content. Both microbial processes (SCR and EEA) were also positively correlated with the PN and POC contents of MFIP. Together with the results of the PCA, the correlations indicate close relationships of various POM variables to VHG on the one side, and to the bacterial variables on the other. This suggests a hierarchical control of bacterial activities by the VHG, linked intermediately by the quantity and quality of POM in the mobile (MFIP) and fixed (biofilm) fractions.

\section{DISCUSSION}

\section{Spatial pattern within subaqueous dune}

A clear spatial pattern of transport and metabolic processes was detected in the subaqueous dune. On the stoss side, the $7 \%$ slope and high flow velocity led to infiltration of overlying surface water. Thereby, suspended particles entered the sediments such that the distribution of MFIP within the dune transect closely followed that of the VHG, peaking on the stoss side. The POM content was also high on the stoss side. Hence, this sandy bedform traps and stores suspended matter, as has previously been described for infiltration zones in gravel-bed mountain rivers (Marmonier et al. 1995). Similarly, in the subaqueous dune, advective particle transport was driven by pressure gradients. Beyond this, our results indicate that infiltration of fine organic matter and intrusion of oxygen led to high bacterial abundance, SCR and EEA on the stoss side of the subaqueous dune.

The investigated dune comprised a broad crestal plateau approximately $10 \mathrm{~m}$ long, where exfiltration prevailed. Due to high flow velocities above the dune, sediment particle size was maximal in the plateau. MFIP and sedimentary POM content, dissolved oxygen concentration as well as bacterial activity were at their minimum. Within the plateau, the upper part was probably more prone to infiltration than the lower part, as indicated by higher MFIP values on the upper plateau than the lower plateau.

Table 3. Results of Spearman rank correlation coefficients $\left(r_{s}\right)$ between microbial and environmental variables; ${ }^{*} p<0.05$; ${ }^{* *} \mathrm{p}<0.01 ;{ }^{* * *} \mathrm{p}<0.001$. (LAP: leucine aminopeptidase; MFIP: mobile fine interstitial particles; PN: particulate nitrogen; POM: particulate organic matter; SCR: sediment community respiration; VHG: vertical hydraulic gradient)

\begin{tabular}{|c|c|c|c|c|c|c|}
\hline Variables & $\begin{array}{l}\text { Bacterial } \\
\text { abundance } \\
\mathrm{n}=20\end{array}$ & $\begin{array}{c}\beta \text {-glucosidase } \\
n=24\end{array}$ & $\begin{array}{l}\text { Exoglucase } \\
\qquad n=24\end{array}$ & $\begin{array}{c}\beta \text {-xylosidase } \\
\mathrm{n}=24\end{array}$ & $\begin{array}{l}\text { LAP } \\
\mathrm{n}=24\end{array}$ & $\begin{array}{l}\text { SCR } \\
\mathrm{n}=24\end{array}$ \\
\hline VHG $(n=24)$ & -0.39 & -0.40 & $-0.52^{*}$ & $-0.48^{*}$ & -0.34 & $-0.41^{*}$ \\
\hline $\operatorname{Sep}(n=12)$ & -0.55 & $-0.74^{* *}$ & $-0.75^{* *}$ & $-0.58^{*}$ & $-0.63^{*}$ & $-0.64^{*}$ \\
\hline $\operatorname{Nov}(n=12)$ & $-0.72^{* *}$ & $-0.75^{* *}$ & $-0.70^{*}$ & $-0.63^{*}$ & $-0.72^{* *}$ & -0.50 \\
\hline Dry mass MFIP & 0.41 & $0.41^{*}$ & $0.45^{*}$ & $0.44^{*}$ & 0.36 & $0.49^{*}$ \\
\hline PN MFIP & 0.38 & $0.49^{*}$ & $0.53^{* *}$ & $0.55^{* *}$ & $0.47^{*}$ & $0.55^{* *}$ \\
\hline Chl $a(n=12)$ & 0.48 & 0.49 & 0.43 & 0.39 & 0.49 & 0.11 \\
\hline Phaeopigments $(n=12)$ & $0.74^{*}$ & $0.85^{* *}$ & $0.90^{* * *}$ & $0.73^{* *}$ & $0.67^{*}$ & $0.73^{* *}$ \\
\hline \multicolumn{7}{|l|}{ Sediment } \\
\hline Total POM & $0.48^{*}$ & $0.65^{* *}$ & $0.50^{*}$ & $0.47^{*}$ & $0.52^{* *}$ & 0.33 \\
\hline $\mathrm{PN}$ & $0.55^{*}$ & $0.74^{* * *}$ & $0.64^{* *}$ & $0.57^{* *}$ & $0.60^{* *}$ & 0.38 \\
\hline $\mathrm{C} / \mathrm{N}(\mathrm{n}=24)$ & -0.34 & -0.28 & $-0.50^{*}$ & $-0.42^{*}$ & -0.34 & -0.24 \\
\hline Sep $(n=12)$ & $-0.98^{* * *}$ & $-0.83^{* *}$ & $-0.71^{* *}$ & $-0.62^{*}$ & $-0.64^{*}$ & -0.45 \\
\hline Nov $(n=12)$ & -0.27 & -0.18 & -0.49 & -0.27 & -0.54 & -0.11 \\
\hline Carbohydrates & $0.68^{* *}$ & $0.79^{* * *}$ & $0.73^{* * *}$ & $0.67^{* * *}$ & $0.61^{* *}$ & $0.49^{*}$ \\
\hline Protein & $0.73^{* * *}$ & $0.79^{* * *}$ & $0.71^{* * *}$ & $0.73^{* * *}$ & $0.70^{* * *}$ & $0.62^{* *}$ \\
\hline
\end{tabular}


On the lee side, exfiltration prevailed, resulting in lower concentrations of MFIP compared to the stoss side. However, reverse-flow (wakes) may have produced some minor infiltration events on the lee side (Carling et al. 2000). Despite the lower infiltration rates on the lee side compared to the stoss side, sedimentary POM content, bacterial abundance and EEA levels were similar on the lee and stoss sides. This may be due to the fact that low flow velocities on the lee side probably resulted in the deposition and trapping of POM. A similar effect was described for a slow-flowing zone downstream of a riffle in a gravel-bed river by Claret et al. (1998).

\section{Extracellular enzyme activities (EEA)}

The general pattern of specific EEA $\left(V_{\max }\right)$ in this study was leucine aminopeptidase $>\beta$-glucosidase $>\beta$ xylosidase $>$ exo-1,4- $\beta$-glucanase. The high activity of leucine aminopeptidase compared to other enzyme activities is probably related to the high proportion of proteins in algal biomass. Besides this, LAP may hydrolize a large number of peptides with L-configuration as substrates (Chróst 1991), whereas carbohydrate-degrading enzymes exhibit high substratespecificities (Chróst 1991). The higher $\beta$-glucosidase activity than $\beta$-xylosidase activity supports the assumption that cellulose is the predominant carbon source for bacteria in sediments, rather than hemicellulose (Sabater \& Romaní 1996, M. Rulík pers. comm.). There were no differences in the EEA pattern between the zones of the subaqueous dune.

\section{Factors determining microbial activity}

Bacterial activity was strongly influenced by VHG. The highest SCR rate and a high level of EEA were found on the stoss side of the dune. This showed that the infiltration of river water, which transfers microbial substrates and dissolved oxygen into the sediments, promoted the microbial activity. SCR rates were also higher in infiltration zones than in exfiltration zones of small gravel-bed rivers, which, however, generally exhibited similar or slightly lower activity levels than the River Elbe (Naegeli et al. 1995, Ingendahl 1999, Ingendahl et al. 2002). Comparable effects of subsurface hydrology on other parameters of microbial activity have been reported for gravel-bed streams and rivers (Jones et al. 1995, Marmonier et al. 1995, Battin 2000). The present results support the model of Hendricks (1993), based on gravel-bed rivers, whereby the infiltration zone is more conductive to aerobic processes such as respiration than the exfiltration zone.
Our present findings suggest that this hypothesis is also applicable to short sand dunes in a large river.

Our results give some insight into the mechanisms connecting hydromorphological and microbiological processes. Both types of processes are connected indirectly via the quantity and quality of organic matter retained in the sediments. Our results indicate that hydromorphological processes lead to accumulation of high-quality sedimentary POM (protein, carbohydrates, PN and phaeopigments) on the stoss and lee sides of the dune, which favour bacterial growth and activity on these sites. High-quality POM (protein and PN content) was also the best predictor for variability of bacterial abundance and production in the lowland river Spree (Fischer et al. 2002b). Recently, close connections have been found between high-quality POM and EEA in fluvial systems (Romaní et al. 1998, Bonin et al. 2000); for example, sediment carbohydrates largely explained the pattern of biofilm esterase activity (Battin 2000). In particular, detritus produced by phytoplankton should form a high-quality substrate for bacteria. The close relationship between microbial activity (SCR and EEA) and phaeopigment content, as found in our study, supports the assumption that phytoplankton detritus is a high-quality substrate for bacteria.

There is some evidence that algal photosynthesis seasonally promotes enzymatic and respiratory activity of sediment bacteria (Jones 1995, Kemp \& Dodds 2001, Romaní \& Sabater 2001). In our study, this functional relationship was indicated by the fact that the $\mathrm{C} / \mathrm{N}$ ratio of sediment, which is a parameter of POM quality, was highly negatively correlated with bacterial variables (abundance and EEA) for September samples only. The $\mathrm{C} / \mathrm{N}$ ratios of sediment and bacterial variables were only weakly correlated in November, probably due to low phytoplankton production and the sharply diminished input of fresh organic material into the sediments. Similar to EEA, the distribution of SCR in the dune was controlled via the quantity and quality of organic matter. In this case, the protein content of sedimentary POM and phaeopigments were the relevant parameters related to enhanced SCR. Total sedimentary POM contributed much less to the prediction of SCR distribution, as was similarly found by Pusch \& Schwoerbel (1994) and by Jones et al. (1995). Significant correlations between total POM content and community respiration were found in the sediments of a gravel bed river by Naegeli et al. (1995) and in lowgradient blackwater streams by Fuss \& Smock (1996), but the protein content of POM was not assessed. These correlations between microbial activities and the presence of high-quality substrates indicate that bacterial abundance adapts quickly to local conditions, which means that bacterial abundance was probably 
not a limiting factor for bacterial activity in most cases. However, spatial heterogeneity of bacterial populations may have contributed to the variability of the observed microbial activity levels (significant correlations between EEA and bacterial abundance in the sediment).

Our results indicate that there were several pools of organic matter in the sediments of the subaqueous dune in the Elbe, differing in their relevance for specific microbiological processes. SCR was most closely related to the sedimentary content of decaying algae, as reflected by the phaeopigments, and of protein. EEA was also closely related to decaying algae and protein, and additionally to elevated sediment contents of carbohydrates and nitrogen. Both microbial processes (SCR and EEA) were also positively influenced by high organic contents of MFIP. This pool of mobile particles, exhibiting a large proportion of high-quality organic matter, is probably especially characteristic for a riverine bedform that is in close hydrological connectivity with the water column. It is hypothesized that these mobile particles are trapped by the sedimentary biofilm, and thus are continuously transferred to the sediment POM pool described above. Furthermore, it can be assumed that microbial activities were also promoted by the presence of metabolically active bacteria colonising the MFIP.
There is evidence that DOC concentration and composition are involved in the control of microbial activity in riverine sediments (Findlay \& Sobczak 2000, Fischer et al. 2002a). However, we found no significant differences in total DOC and DOC fractions of interstitial water samples between the morphodynamic zones of the subaqueous dune. Large proportions of DOC sorbed to the biofilm are not instantly turned over, but remain in the biofilm as a reservoir (Fiebig 1997), which could buffer direct effects of DOC depletion in interstitial water. A fast microbial turnover, especially of easily utilisable DOC fractions (polysaccharides and low-molecular-weight compounds) could mask possible gradients of these fractions along the transect of the dune.

\section{Hierarchical controls on microbial activity within subaqueous dune}

The regulation of microbial activity in the subaqueous dune can be conceptually summarized by a 2-stage regulatory hierarchy (Fig. 7) that connects hydromorphological processes and microbial activities via the input of easily degradable microbial substrates (cf. Fischer et al. 2003). The standing stock of these microbial substrates represents an intermediate control level.

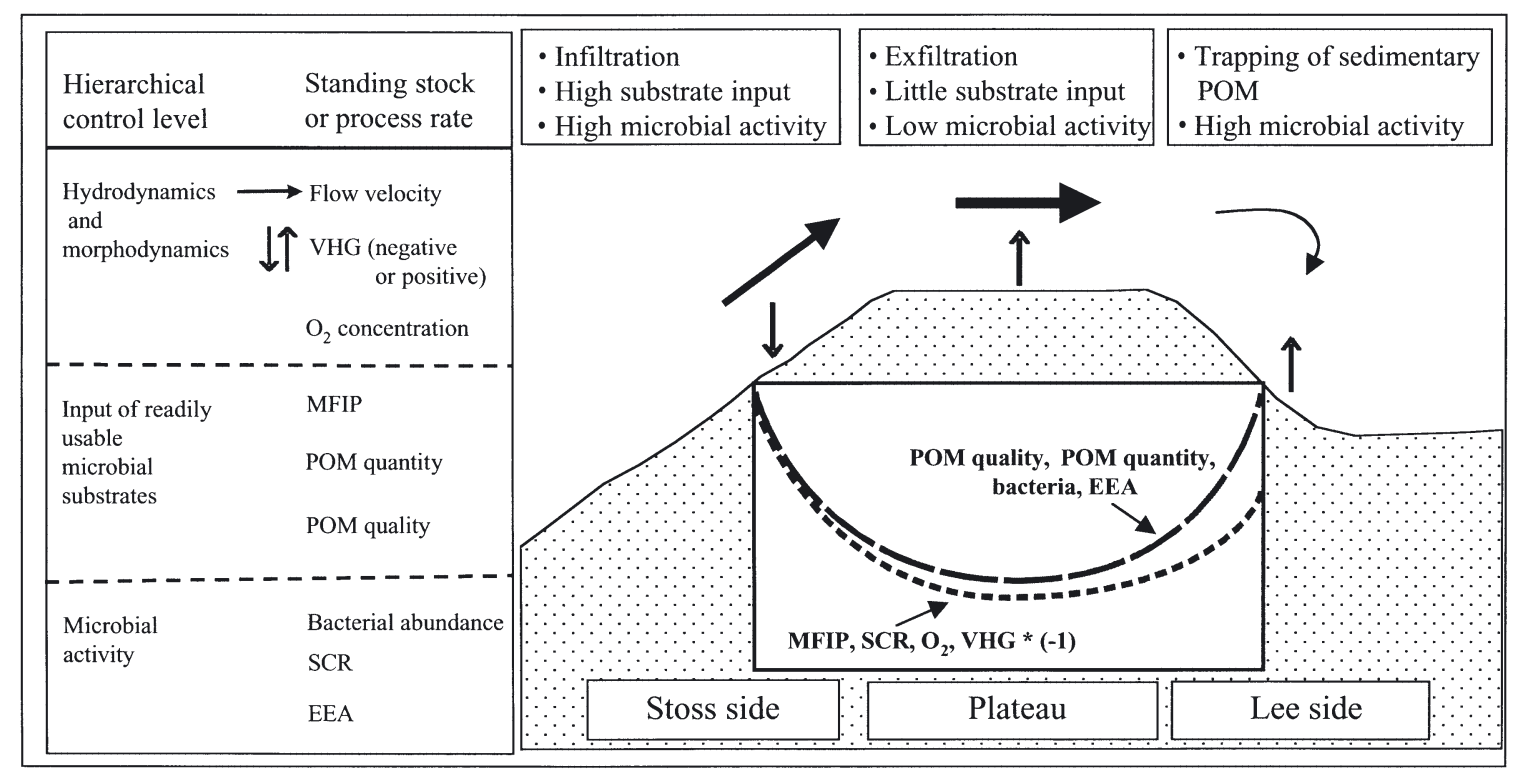

Fig. 7. Schematic model of spatial patterns of hydrodynamics, morphodynamics, fine particles, particulate organic matter and microbial activity within subaqueous dune. Direction and relative level of the variables are represented by direction and relative size of arrows and by relative extension of line (in similarity to the percentage increase) compared to plateau site, respectively, EEA: extracellular enzyme activities; MFIP: mobile fine interstitial particles; POM quantity: total particulate organic matter content; POM quality: sedimentary content of carbohydrates, protein, phaeopigments; SCR: sediment community respiration; VHG: vertical hydraulic gradient 
First, hydrodynamic and morphodynamic processes lead to the formation of 3-dimensional bedforms with a distinct spatial pattern of infiltration and exfiltration of river water, supplemented by sedimentation processes in the hydrological dead zone on the lee side. Hence, 2 processes are involved in the retention of POM: filtering of fine suspended particles from the river water on the stoss side of the dune, and sedimentation of (presumably) bigger particles on the lee side. This hydrodynamic/morphodynamic pattern results in a characteristic spatial distribution in respect to dissolved oxygen availability, input of readily degradable organic matter and reactive nitrogen, and probably of bacteria themselves, as they colonise the entrapped particles.

Second, the variability of dissolved oxygen availability and the standing stocks of easily degradable microbial substrates exert a clear 'bottom-up' control on microbial activity. This pathway of control on microbial activity is supposed to be the most important pathway, as other potential control mechanisms, such as physical impact by the constant transport of sandy sediments, or the 'top-down' control by protozoa (Gücker \& Fischer 2003) and large invertebrate populations (Barton \& Smith 1984, Brunke et al. 2002), reach only minor significance in sandy river sediments.

The same controls on microbial activity presumably also apply to the mobile long-duned sediments present in the central channel of the River Elbe and other rivers (Rutherford et al. 1991, Carling et al. 2000), which showed a similar but slightly lower level of microbial activity (authors' unpubl. data).

\section{CONCLUSIONS}

Large rivers have rarely been studied by hydrobiologists because of difficult access, especially in regard to the sediments. In order to determine the functional characteristics of a subaqueous dune in a large river, we investigated sediments within 3 morphodynamic zones (stoss side, crestal plateau, lee side) of a subaqueous dune in the 8th-order River Elbe. The morphodynamic differentiation of this subaqueous dune resulted in the formation of distinct functional zones in the sediments, with the stoss and the lee sides being focal zones of particulate matter retention due to infiltration and sedimentation processes. In these zones, bacterial abundance and most variables of microbial activity were significantly higher than on the plateau. The remarkable relationship between morphological structure and microbial functioning in such sandy sediments can be conceptually summarized by a 2 -stage regulatory hierarchy, as microbial activities were controlled directly by the availability of metabolic resources, and indirectly by hydromorphological pro- cesses. As a result of these processes, subaqueous dunes represent an efficient POM filter. Hence, the presence of dunes may enhance the carbon mineralisation rate and increase the heterotrophic capacity of the river ecosystem in surface sediments relative to a flat river bottom. Beyond this, our results show that even in a high-order river, there is a high sedimentary activity of extracellular enzymes degrading labile organic substances, which are probably produced by the planktonic algae luxuriating in many large rivers world-wide. Thus, as hypothesized by the revised 'riverine productivity model' (Thorp \& Delong 2002), the metabolism of organic matter in high-order rivers seems to be partially independent of allochthonous carbon inputs from the headwaters.

Acknowledgements. This study was financially supported by the Bundesministerium für Bildung und Forschung (BMBF, FKZ 0339602). We thank B. Kiergaßner and A. Ratzinger for their technical assistance in the field and in the laboratory, the Federal Administration for Water and Navigation (WSV) for providing water depth data, the Wassergütestelle Elbe (Hamburg) for providing physicochemical data of Elbe river water, and H. P. Grossart for valuable comments on an earlier draft of the manuscript.

\section{LITERATURE CITED}

Barton DR, Smith SM (1984) Insects of extremely small and extremely large aquatic habitats. In: Resh $\mathrm{VH}$, Rosenberg DM (eds) The ecology of aquatic insects. Praeger, New York, p 456-483

Battin TJ (2000) Hydrodynamics is a major determinant of streambed biofilm activity: from the sediment to the reach scale. Limnol Oceanogr 45:1308-1319

Battin TJ, Sengschmitt D (1999) Linking sediment biofilms, hydrodynamics, and river bed clogging: evidence from a large river. Microb Ecol 37:185-169

Bonin HL, Griffiths RP, Caldwell BA (2000) Nutrient and microbiological characteristics of fine benthic organic matter in mountain streams. J North Am Benthol Soc 19: 235-249

Bou C, Rouch R (1967) Un nouveau champ de recherches sur la faune aquatique souterraine. C R Hebd Séances Acad Sci 265:369-370

Brunke M, Fischer H (1999) Hyporheic bacteria-relationships to environmental gradients and invertebrates in a prealpine stream. Arch Hydrobiol 146:189-217

Brunke M, Gonser T (1997) The ecological significance of exchange processes between rivers and groundwater. Freshw Biol 37:1-33

Brunke M, Gonser T (1999) Colmation and depth filtration within streambeds: retention of particles in hyporheic interstices. Int Rev Gesamten Hydrobiol 84:99-117

Brunke M, Hoffmann A, Pusch M (2002) Association between invertebrate assemblages and mesohabitats in a lowland river (Spree, Germany): a chance for predictions? Arch Hydrobiol 154:239-259

Carling PA, Williams JJ, Kelsey AD (2000) The morphodynamics of fluvial sand dunes in the River Rhine, near Mainz, Germany. II. Hydrodynamics and sediment transport. Sedimentology 47:253-278 
Chróst RJ (1991) Environmental control of the synthesis and activity of aquatic microbial ectoenzymes. In: Chróst RJ (ed) Microbial enzymes in aquatic environments. Springer-Verlag, Heidelberg, p 42-50

Chróst RJ (1994) Microbial enzymatic degradation and utilisation of organic matter. In: Chróst R, Overbeck J (eds) Microbial ecology of Lake Plußsee. Springer-Verlag, Heidelberg, p 118-174

Claret C, Marmonier P, Boissier JM, Fontvieille D, Blanc P (1997) Nutrient transfer between parafluvial interstitial water and river water: Influence of gravel bar heterogeneity. Freshwat Biol 37:657-670

Claret C, Marmonier P, Bravard JP (1998) Seasonal dynamics of nutrient and biofilm in interstitial habitats of two contrasting riffles in a regulated large river. Aquat Sci 60: $33-55$

Deutsche Einheitsverfahren (1985) Deutsche Einheitsverfahren zur Wasser-, Abwasser- und Schlammuntersuchung. DIN 38412, Teil 16 (1996). Verlag Chemie, Weinheim

Elliott AH, Brooks NH (1997) Transfer of nonsorbing solutes to a streambed with bedforms: theory. Water Resour Res 33: 123-136

Fiebig DM (1997) Microbiological turnover of amino acids immobilized from groundwater discharge through hyporheic sediments. Limnol Oceanogr 42:763-768

Findlay S, Sobczak WV (2000) Microbial communities in hyporheic sediments. In: Jones JB, Mulholland PJ (eds) Streams and ground waters, Academic Press, London, p 287-306

Fischer H, Pusch M (2001) Comparison of bacterial production in sediments, epiphyton and the pelagic zone of a lowland river. Freshw Biol 46:1335-1348

Fischer H, Sachse A, Steinberg CEW, Pusch M (2002a) Differential retention of dissolved organic carbon (DOC) by a bacterial community in river sediments. Limnol Oceanogr 47:1702-1711

Fischer H, Wanner SC, Pusch M (2002b) Bacterial abundance and production in river sediments as related to the biochemical composition of particulate organic matter (POM). Biogeochemistry 61:37-55

Fischer H, Sukhodolov A, Wilczek S, Engelhardt C (2003) Effects of flow dynamics and sediment movement on microbial activity in a lowland river. River Res Applic 19: $473-482$

Fuss CL, Smock LA (1996) Spatial and temporal variation of microbial respiration rates in a blackwater stream. Freshw Biol 36:339-349

Gücker B, Fischer H (2003) Flagellate and ciliate distribution in sediments of a lowland river: relationships with environmental gradients and bacteria. Aquat Microb Ecol 31: $67-76$

Hendricks SP (1993) Microbial ecology of the hyporheic zone: a perspective integrating hydrology and biology. J N Am Benthol Soc 12:70-78

Hoppe HG (1993) Use of fluorogenic model substrates for extracellular enzyme activity (EEA) measurement of bacteria. In: Kemp PF, Sherr BF, Sherr EB (eds) Handbook of methods in aquatic microbial ecology. Lewis Publishers, Boca Raton, FL, p 423-431

Huettel M, Ziebis W, Forster S (1996) Flow-induced uptake of particulate matter in permeable sediments. Limnol Oceanogr 41:309-322

Ingendahl D (1999) Der Reproduktionserfolg von Meerforelle (Salmo trutta L.) und Lachs (Salmo salar L.) in Korrelation zu den Mileubedingungen des hyporheischen Interstitials. $\mathrm{PhD}$ thesis, University of Cologne

Ingendahl D, Haseborg ter E, Meier M, Most van der O,
Steele H, Werner D (2002) Linking hyporheic community respiration and inorganic nitrogen transformations in the River Lahn (Germany). Arch Hydrobiol 155:99-120

Itzhaki RF, Gill DM (1964) A micro-biuret method for estimating proteins. Anal Bioch 9:401-410

Jones JB (1995) Factors controlling hyporheic respiration in a desert stream. Freshw Biol 34:91-99

Jones JB, Fisher SG, Grimm NB (1995) Vertical hydrologic exchange and ecosystem metabolism in a Sonoran desert stream. Ecology 76:942-952

Kemp MJ, Dodds WK (2001) Centimeter scale patterns in dissolved oxygen and nitrification rates in a prairie stream. J North Am Benthol Soc 20:347-357

Kostaschuk R (2000) A field study of turbulence and sediment dynamics over subaqueous dunes with flow separation. Sedimentology 47:519-531

Marmonier P, Fontvielle D, Gibert J, Vanek V (1995) Distribution of dissolved organic carbon and bacteria at the interface between the Rhône River and its alluvial aquifer. J N Am Benthol Soc 14:382-392

Marxsen J, Tippmann P, Heininger P, Preuß G, Remde A (1998) Aktivität. In: Vereinigung für allgemeine und angewandte Mikrobiologie (ed) Mikrobiologische Charakterisierung aquatischer Sedimente. Oldenbourg, München, p 92-104

Naegeli MW, Uehlinger U (1997) Contribution of the hyporheic zone to ecosystem metabolism in a prealpine gravel-bed river. J N Am Benthol Soc 16:794-804

Naegeli MW, Hartmann U, Meyer E, Uehlinger U (1995) POM-dynamics and community respiration in the sediments of a floodprone prealpine river (Necker, Switzerland). Arch Hydrobiol 133:339-347

Packman AI, Bencala KE (2000) Modelling surface-subsurface hydrological interactions. In: Jones JB, Mulholland PJ (eds) Streams and ground waters. Academic Press, London, p 45-80

Porter KG, Feig YS (1980) The use of DAPI for identifying and counting aquatic microflora. Limnol Oceanogr 25:943-948

Pusch M, Fiebig D, Bretlar I, Eisenmann H and 5 others (1998) The role of micro-organisms in the ecological connectivity of running waters. Freshw Biol 40:435-495

Pusch M, Schwoerbel J (1994) Community respiration in hyporheic sediments of a mountain stream (Steina, Black Forest). Arch Hydrobiol 130:35-52

Rausch T (1981) The estimation of micro-algal protein content and its meaning to the evaluation of algal biomass. I. Comparison of methods for extracting protein. Hydrobiologia 78:237-251

Romaní AM, Sabater S (1999) Epilithic ectoenzyme activity in a nutrient-rich Mediterranean river. Aquat Sci 61:122-132

Romaní AM, Sabater S (2001) Structure and activity of rock and sand biofilms in a Mediterranean stream. Ecology 82: $3232-3245$

Romaní AM, Butturini A, Sabater F, Sabater S (1998) Heterotrophic metabolism in a forest stream sediment: surface versus subsurface zones. Aquat Microb Ecol 16: 143-151

Rutherford JC (1994) Mixing between sediments and river water. In: Rutherford JC (ed) River mixing. John Wiley \& Sons, Chichester, p 283-320

Rutherford JC, Wilcock RJ, Hickey CW (1991) Deoxygenation in a mobile bed river. I. Field studies. Water Res 25: 1487-1497

Sabater S, Romaní A (1996) Metabolic changes associated with biofilm formation in an undisturbed Mediterranean stream. Hydrobiologia 335:107-113

Sauer W, Schmidt A (2001) Die Bedeutung suspendierten 
Sandes für die Sohlhöhenentwicklung der Elbe. Wasserwirtschaft 91:443-449

Sinsabaugh RL, Findlay S (1995) Microbial production, enzyme activity, and carbon turnover in surface sediments of the Hudson River Estuary. Microb Ecol 30(2):127-141

Sinsabaugh RL, Linkins AE (1990) Enzymic and chemical analysis of particulate organic matter from a boreal river. Freshw Biol 23:301-309

Thioulouse J, Chessel D, Doledec S, Oliver JM (1997) ADE4:a multivariate analysis and graphical display software. Stat Comput 7:75-83

Thorp JH, Delong MD (2002) Dominance of autochthonous autotrophic carbon in food webs of heterotrophic rivers. Oikos 96:543-550

Underwood GJC, Parkers RJ (1995) The measurement of microbial carbohydrate exopolymers from intertidal sediments. Limnol Oceanogr 40:1243-1253

Valett HM, Dahm CN, Campana ME, Morrice JA, Baker MA, Fellow CS (1997) Hydrologic influences on groundwater

Editorial responsibility: Kevin Carman,

Baton Rouge, Louisiana, USA surface water ecotones: heterogeneity in nutrient composition and retention. J N Am Benthol Soc 16:239-247

Vervier P, Naiman RJ (1992) Spatial and temporal fluctuations of dissolved organic carbon in surface flow of the Stillaguamish River (Washington, USA). Arch Hydrobiol 123: 401-421

Vervier P, Dobson PM, Pinay G (1993) Role of interaction zones between surface and ground waters in DOC transport and processing: consideration for river restoration. Freshw Biol 29:275-284

Wang Y, Büchele B, Nestmann F (2002) Wirkung instationären Abflussverhaltens und von Buhnen auf den Dünentransport in der Elbe (in wasserbaulichen Laborversuchen). In: Nestmann F, Büchele B (eds) Morphodynamik der Elbe. Eigenverlag Universität Karlsruhe, Karlsruhe, p 279-301

Williams DD (1993) Nutrient and flow dynamics at the hyporheic/groundwater interface and their effects on the interstitial fauna. Hydrobiologia 196:149-158

Submitted: September 29, 2003; Accepted: March 17, 2004 Proofs received from author(s): June 8, 2004 